INTENSIVE JOURNAL

http://ojs.uniska-bjm.ac.id/index.php/EJB

E-ISSN 2620-4746

April 2021, Vol 4 No.1

\title{
THE EFFECT OF COMPUTER ASSISTANT INSTRUCTION ( CAI ) ON ADVANCED READING
}

\author{
Aprillia Widya Lestari \\ Muhammadiyah University of Metro, Lampung, Indonesia \\ Email:aprillia.lestary@gmail.com \\ Fenny Thresia \\ Muhammadiyah University of Metro, Lampung, Indonesia \\ fenny.thresia@yahoo.com
}

\begin{abstract}
The study was conducted to find out the significant influence of Computer Assisted Instruction (CAI) on advanced reading at fourth semester of English Department Muhammadiyah University of Metro. Computer Assisted Instruction (CAI) is a technique to give instruction by using computer to the students and instructional approach where a computer is used to evaluate the learning outcomes. This research is an experimental research and the subject of the research are 40 students at fourth semester of English department. There are two 20 students for control group and 20 students for experimental group. The result of average score of pre-test at experimental group and control group are 1.36 and 1.39. It shows that the control group is higher than the experimental group. However, the result of the post test of the experimental group is higher the control group, they are 1.71 for the experimental group and 1.41 for the control group. It can be conclude that, there is significant influence in students' reading comprehension after being taught by using Computer Assisted Instruction (CAI).
\end{abstract}

Key words: CAI; Advanced reading; Reading comprehension.

\section{INTRODUCTION}

Reading is an important skill because it functions as literacy skill. It means that when someone is going to master certain knowledge, the first thing they should be able to read. By reading, students will understand certain knowledge and will get more knowledge. Even In this technology era, reading also plays an important role. Nowadays, everyone uses technology in daily life and most of electronic stuffs, warnings in transportations, labels and instructions in gadgets, are written in English. Someone should have reading comprehension and be able to read in English so he can operate those stuffs appropriately.

Intensive Journal, Vol. 4(1), 2021 
Furthermore, reading comprehension is a critical skill for students to learn. Some students are able to analyze the pictures, fluently read the text, and recognize certain words but some students are not able to fully understand the text. In addition, Sudjana in Kosasih, (2014) states that the results of students' learning outcomes are influenced by two main factors, internal and external. Internal factor is from the student itself that influence the learning outcomes, namely the ability of the student itself. Internal factors which include intelligence, interest, and attention to learning motivation and physical and health conditions. External factors that influence students about how the role of the environment influences student learning outcomes.

The researcher got the data pre-survey of the students reading comprehension score at third semester of English department Muhammadiyah University of Metro from the reading lecturer as follow: from the data the researcher find out from 45 students at third semester of English department. Then, the students that got high score are 6 students with the percentage of $13 \%$, and there are 9 students who got average category and got the percentage of $20 \%$, and then there are 30 students who got low category and got the percentage of $67 \%$. Based on those data, it can be concluded that students is still low in reading comprehension. Therefore, the researcher assumes that students need some attention and interest technique to promote students' reading comprehension especially in advanced reading. Because of that, the researcher using Computer Assisted Instruction ( CAI ) as a technique for students, so they can study easily because students can be given various levels of control over their own learning, then teaching can be adjusted to the individual needs of students and feedback about student performance . Fraser et al., (2010) has identified that Computer Assisted Instruction (CAI), proving an efficient and effective media in education.

There are some previous researches as the comparison. The first previous research is conducted by Sedega and Jonathan (2017) entitled "The Effect of Computer Assisted Instruction (CAI) on Senior High School Students' Achievement" from Ghana University. The result of this research is experimental group had much gain on the intervention than the control group with the result 8.71 and 7.02 . it can be concluded that CAI was equally effective for students in the experimental group

The second research is conducted by Suleman and Naseer (2017) entitled "' Effects of Computer Assisted Instruction (CAI) on Students' Academic Achievement " from Kohat University, Pakistan. From this research, mean values clearly show that experimental group (mean=96.87, $\mathrm{SD}=6.49$ ) showed better performance than control group (mean=70.21, $\mathrm{SD}=8.73$ ). it means, computer assisted instruction (CAI) has a significant positive effect on students' academic achievement.

The last research by Gautam and Kaur (2015) entitled 'The Effect of Computer Assisted Instructions on Attitude Towards Environmental Pollution of Secondary School Students" from Kohat University. The result is gain score of experimental group is 22.54 and gain score of the controlled group is 20.71. The conclusion is Computer Assisted Instruction (CAI) as a technique was more effective in creating a positive attitude towards prevention of environmental pollution among students.

Intensive Journal, Vol. 4(1), 2021 
For the reason, the researcher takes some previous research overview to support this research. The differences of this research from previous research overview is the previous research they used senior high school for the sample and in this research used university for the research . The researcher will do the technique in different types and subject. In this research, the researcher takes the experimental research of advanced reading in fourth grade at English department Muhammadiyah University of Metro. The researcher assured that CAI is effective to increase the students' reading skills especially in advanced reading.

\section{LITERATURE REVIEW}

The theoretical review of this research includes the concept of reading comprehension, advanced reading and computer assisted instruction ( CAI ) technique. The explanation can be seen as follow :

\section{The Definition of Reading}

Reading is a process when readers learn something from what they read and involve it in an academic context as a part of education. According to Akbar et al,. (2016) as one of language skills, reading roles so urgently in communication. Reading is the receptive skill, meaning that the way in which people extract meaning from the discourse they see. Iftanti (2015) states that reading is perceived as a complex act of communication in which a number of textual, contextual, and reader-based variables to produce comprehension.

In conclusion, reading is one of language skills which there is an interaction between writer and reader and the process to convey the messages. In addition, reading consists of two processes namely word recognition and comprehension.

\section{Types of reading}

According Patel and Jain (2010) there are four types of reading, there are :

1) Intensive reading

According to Hasibuan and fitri (2018) intensive reading is related to further progress in language learning under the teachers' guidance. Furthermore, Soemantri and Susany (2011) says that the goal of this reading is to read shorter text. This reading is done to carry out to get specific information.

2) Extensive reading

According to Ferdila (2014) Extensive reading is the reading for pleasure. The reader wants to know about something but the reader does not care about specific or important information after reading. Usually people read for to keep them update.

3) Reading aloud

Mulyawati (2017) states that reading aloud also play important role in teaching of English. Teacher should know that the training of reading aloud must be given at primary level because it is the base of word pronunciation.

4) Silent reading

Intensive Journal, Vol. 4(1), 2021 
Silent reading is a very important skill in teaching of English. According to Sinambela (2015) silent reading should be employed to increase reading ability among learners. Silent reading is done to acquire a lot of information.

2.1.2 The aim of reading

According to Ariawan and Pratiwi (2017) the aims of reading are:

1) Reading for details of facts

2) Reading for the sequence or organization.

3) Reading to classify

4) Reading to compare

\section{Reading Comprehension}

According to Ortlieb (2014) reading comprehension is the understanding resulted through the process by which the meaning of a written text is understood. Stahl (2011) defined that reading comprehension is the ability to identify meaningful relations between the various parts of a text and between these parts and the readers' background knowledge. Nunan (2011) states that in reading comprehension students should understand reading aspects, namely: 1) identifying main ideas, 2) identifying supporting details, 3) understanding vocabulary, 4) identifying references and 5) making conclusions. In addition, Auzar (2012) state that students are expected to be able to evaluating texts relating to special texts such as short and complete texts commonly used in the TOEFL reading test.

\section{Advanced Reading}

According to Suprijono (2016) Advanced is a way of learning to get new knowledge associated with existing knowledge on learning. Rustiani (2020) argues that advanced learning directs students to the material to be learned, and helps students to recall related information that is used to help instill new knowledge. Advance learning model has three purposes, namely:

1) Provide a conceptual framework for learning to occur next.

2) Carefully chosen so that it can be a liaison between a series of student information now and new learning.

3) As a bridge the cognitive structure that will be obtained.

According to Gagen (2012) obviously proficient reading is more complex correct phonologic processing. After foundational skills are established it is equally important to help the student develop advanced or higher level skills including handling multi syllable word, building fluency, expanding vocabulary and developing comprehension skills and strategies. In conclusion, advanced learning designed to strengthen the cognitive structure of students.

\section{Computer Assisted Instruction ( CAI )}

Based on Daramola and Asuquo (2014) Computer-assisted instruction (CAI) is an instructional approach where a computer is used to communicate the instructional materials and evaluate the learning outcomes. CAI refers to virtually any sort of computer application in instructional settings comprising of drill and practice, simulations, instructional exercises, supplementary exercises, instructional 
management, database development, programming, composing using word processors, and other different applications.

\section{Typical Computer Assisted Instruction (CAI)}

There are some typical of Computer Assisted Instruction ( CAI ) based on Wena (2011).

1) Text or multimedia content

2) Multiple-choice questions

3) Problems

4) Immediate feedback

5) Notes on incorrect responses

6) Summarizes students' performance

7) Exercises for practice

8) Worksheets and tests.

\section{The advantages of CAI}

1) Give students the opportunity to solve problems individually.

2) Provides an interesting presentation with animation.

3) Provides a wide and varied choice of learning content.

4) Able to activate and stimulate teaching methods properly.

5) Improve students' understanding of the material presented.

6) Stimulate students to learn with enthusiasm because the material presented is easily understood by students.

7) Students can evaluate because of direct feedback.

\section{The disadvantages of CAI}

1) May feel overwhelmed by the information and resources available

2) Over use of multimedia may divert the attention from the content

3) Learning becomes too mechanical

4) Non availability of good CAI packages

5) Lack of facilities

Some of the weaknesses of CAI can be overcome by providing computer equipment in learning. This is in line with the development of the era that is the role of computers needed for knowledge transfer on a broader scale. In addition, teachers are required to have computer skills so that learning is more innovative.

\section{RESEARCH METHODS}

Arikunto (2013) research design can be interpreted as a plan structured work in terms of relations between variables in a manner comprehensive in such a way that the results of his research can provide answers for research questions. The researcher applies quantitative research method specifically in Quasi Experimental Design. In this research, the researcher used experimental research. The kind of design is, there were two groups of classes involved. The researcher gave some steps, they are pretest, treatment, and post-test. The researcher gave different treatment to both group, the first group was experimental group which used CAI technique, while the second group was control group which did not use CAI technique. There are two variable in 
this research, they are $\mathrm{Y}$ ( reading comprehension ) as dependent variable and X (CAI technique) as independent variable.

The whole students in fourth semester of English department Muhammadiyah University of Metro are decided as population of the research. The total population of this research is 40 students. The researcher takes the sample by using random sampling. The researcher gets A class which consist of 20 students for experimental class and B class which consist of 20 students for control class.

The researcher gave a test as an instrument in this research. The pre-test is given to the students to measure their reading skill before the treatment and the post-test given to measure their reading ability after giving the treatment. After all of the test is reliable then the researcher conducted pre-test before treatment and gave post-test after the treatment. In this study, the type of reading test in pre-test and post-test.The score of the test is based on criteria on the reading test rubric, those are main idea, context, reference, fact, conclusion .

\section{FINDINGS}

Before conducting the experiment, the researcher gave the pre test. The researcher gave multiple choice questions to find out how far the students understand advanced reading. After conducting a pre-test, the researcher gave the treatment in experimental class. The aim of treatment is to develop the students' reading comprehension. Then, in control class the researcher gave the treatment without CAI for the comparison. After conducting the experiment, the researcher gave the post test. The aim is to know the extent of student improvement in reading comprehension after giving treatment. Researcher gave pre-test before giving the treatment. The pre-test was given to 40 students which consist of 20 students in experimental class and 20 students in control class.

Based on data frequency distribution of pre-test in experimental class, there are 15 students who got low category between $0.0-1.5,5$ students got average category between $1.6-2.5$ and there is no students who got high category between $2.6-3$.0. It has difference with control class. Based on data frequency distribution of pre-test in control class, there are 14 students who got low category between $0.0-1.5$, 6 students got average category between $1.6-2.5$ and there is no students who got high category between $2.6-3.0$.

The mean of 1.36 for the experimental group while 1.39 and for the control group. It can be concluded that in pre-test the score of control class higher then experimental class. After getting the data of test, the researcher found the data frequency distribution of post-test in experimental class, there are 6 students who got low category between $0.0-1.5,13$ students got average category between $1.6-2.5$ and there is 1 student who got high category between 2.6-3.0. It has difference with control class. Based on data frequency distribution of post-test in control class, there are 7 students who got low category between $0.0-1.5,13$ students got average

Intensive Journal, Vol. 4(1), 2021 
category between $1.6-2.5$ and there is no students who got high category between $2.6-3.0$.

The mean of 174 for the experimental group while 1.41 and for the control group. It can be concluded that in post-test the score of experimental class higher then control class.

In this way, the researcher utilized Chi-square formula. Theoretically, if the value of $p$ is higher than 0.05 , the data distribution is normal. The following table is the summary of the result the computation by using Chi-square formula:

Table 1 Results of Normality Test by Chi-square

\begin{tabular}{c|c|c|c|c}
\hline \multicolumn{5}{|c|}{ Test Statistics } \\
\hline & Pretest_experiment & Pretest_control & $\begin{array}{c}\text { Posttest_expperim } \\
\text { ent }\end{array}$ & $\begin{array}{c}\text { Posttest_contro } \\
1\end{array}$ \\
\hline Chi-Square & $6.400^{\mathrm{a}}$ & $10.600^{\mathrm{a}}$ & $3.800^{\mathrm{b}}$ & $9.400^{\mathrm{a}}$ \\
Df & 5 & 5 & 6 & 5 \\
Asymp. Sig. & .269 & .060 & .704 & .094 \\
\hline
\end{tabular}

On the basis of the table above, it could be described that both the values of normality test of pre test experimental and control groups (Asymp. Sig. (2-tailed) were higher than 0.05 . They were 0.269 and 0.060 so it indicated that the data distribution was normal.

\section{Result of Homogenity}

The researcher also conducted the data students of homogeneities variance from both samples to prove whether the both samples have the variant equality or not. Theoretically, if the value of F-test obtained (Fo) is lower than the value of $\mathrm{F}$ table $(\mathrm{Ft})$ the data are homogenous. The result of calculation can be seen in the table below:

Table 2 Result of Homogeneity Test

\begin{tabular}{c|c|c|c|}
\hline \multicolumn{4}{|c|}{ Test of Homogeneity of Variances } \\
\hline PRE_TEST & df1 & df2 & Sig. \\
\hline Levene Statistic & 1 & 38 & .544 \\
\hline .374 &
\end{tabular}

The interpretation of the table above is the value of F-test obtained (Fo) was 0.374 and $\mathrm{Ft}$ was 4.10 at degree of freedom 1:38. It meant that the two groups were homogeneous because the value of Fo is lower than that of Ft $(0.374<4.10)$.

4.3.3 Result of hypothesis test. After analyzing the data, the researcher got the average score and variances of those groups. However, before analyzing the hypothesis, it is better to see the difference of mean score in the pre test and post test either for experimental group or the control group. The mean difference of reading comprehension can be seen in the table below

Intensive Journal, Vol. 4(1), 2021 
THE EFFECT OF COMPUTER ASSISTANT INSTRUCTION (CAI) ON ADVANCED READING

Table 3 The Score of Mean Difference of English Reading Comprehension

\begin{tabular}{c|c|c|c|c}
\hline Groups & $\begin{array}{c}\text { Number of } \\
\text { Participant }\end{array}$ & $\begin{array}{c}\text { Mean of } \\
\text { Pretest score }\end{array}$ & $\begin{array}{c}\text { Mean of } \\
\text { Post test } \\
\text { score }\end{array}$ & Improvement \\
\hline Experiment & 20 & 1.36 & 1.74 & 0.38 \\
\hline Control & 20 & 1.39 & 1.41 & 0.02 \\
\hline
\end{tabular}

Then, to prove the hypothesis, the researcher used $t$-test formula. The result of analysis indicated that the value of $t$ obtained (2.199) was higher than that of $t$ table (2.02) at the significance level 0.05 and the significance $(0.000)$ was lower than 0.05 . That is why, the hypothesis is accepted. It means that teaching reading comprehension using the CAI at the fourth semester students is effective.

\section{DISCUSSION}

In this section, the researcher discusses the research findings which includes the meaning the test result and the effectiveness of the treatment. The result of pre-test shows that the average score of the experimental group and the control group are 1.36 and 1.39. From the score of two groups, the result shows that the control group is better than the experimental group. However, the result of the post test of the experimental group is higher the control group; they are 1.71 for the experimental group and 1.41 for the control group. Furthermore, the hypothesis testing indicates that the experimental group is significantly higher than the control group. Based on the result of the investigation, it is found that there is any significant difference in reading comprehension between students taught using CAI and without using CAI.

\section{CONCLUSION}

There is any significant influence in students' reading comprehension before and after being taught by using Computer Assisted Instruction (CAI ) at fourth semester in English department Muhammadiyah university of Metro. They are proven by the result of pretests and posttests. Before the students were given treatments, the average of students reading comprehension are low but after the researcher gave CAI in learning and teaching activities, the students are developed. The t-test measurement obtained (3.079) was higher than that of $t$ table (2.02) at the significance level 0.05 and the significance $(0.000)$ was lower than 0.05 .

\section{REFERENCES}

Akbar, S., Sahin, M. \& Yaykiran, Z. 2016. The effect of reading comprehension on the performance in science and mathematics. journal of education and practice, $7(16), \mathrm{p} .8-12$

Ariawan, V., \& Pratiwi, I. M. 2017. Implementing joyful learning strategy using treasure clue game method in order to improve reading comprehension skill. Jurnal Prima Edukasia, 5(2) p.203-210.

Intensive Journal, Vol. 4(1), 2021 
THE EFFECT OF COMPUTER ASSISTANT INSTRUCTION (CAI) ON ADVANCED READING

Auzar. 2012 . Keberkesanan penggunaan perisian asas membaca. GEMA Online Journal of Language Studies, 12(2) p.629-644.

Ferdila, R. 2014 . The use of extensive reading in teaching reading . Journal of English and Education, 2(2), p.68-80

Fraser, D.M., Pillay, R., Tjatindi, L., \& Case, J.M. 2010. Enhancing the learning of fluid mechanics using computer simulations. Journal of Engineering Education, 96(4), p.381-388.

Gagen, M.R. 2012 . Advanced Skills Necessary for Proficient Reading: Overview of Key Higher Level or Advanced Reading Skills. http://righttrackreading.com/advancedskills.html. May, 5th 2020 (12.30 )

Gautam \& Kaur. 2015 . Effect Of Computer Assisted Instructions On Attitude Towards Environmental Pollution Of Secondary School Students . MIER Journal of Educational Studies, 5(1), p. 39-51

Hasibuan \& Fitri. 2018. The Implementation of Trading Place Strategy to Improve the Students' Ability in Reading Comprehension of Report Text at Eight Grade Of Mts S. Al-Husna Marindal Medan Academic Year 2018/2019.Proceedings of the $1^{\text {st }}$ Annual International Conference on Language and Literature (AICLL), 18-19 April 2018, Fakultas Sastra, UISU, Medan, Indonesia.Pp131-139.

Iftanti, E. 2015 . What makes EFL students establish good reading habit in English. International Journal of Education and Research, 3(5), 365-374

Kosasih, E. 2014 . Strategi belajar dan pembelajaran implementasi kurikulum 2013. Bandung: Yrama Widya

Mulyawati. 2017 . Reading Comprehension Achievement: A Comparative Study between Science and Social Science Students. Studies In English Language And Education journal, 4(1), p.92-104

Nunan, D. 2011. Practical English Language Teaching. New York: McGraw Hill. on Secondary School Students' Achievement in Introductory Technology in Ilorin, Nigerian. The Nigeria Journal of Educational Media and Technology, 12(1), 98-107.

Patel \& Jain. 2010 . English Language teaching (Methods, Tools Techniques) . First Published. Sunrise Publishers. Jaipur.

Rustiani. 2020. Penerapan Model Pembelajaran Advance Organizer Dalam Upaya Peningkatan Hasil Belajar . Diferensial Journal. 1(1), p.23-28

Sedega , M.M., \& Jonathan A., 2017. Effect Of Computer Assisted Instruction (Cai) On Senior High School Students' Achievement At Pie Chart And Histogram In Core Mathematics. British Journal of Education. 5(9), p.4568

Intensive Journal, Vol. 4(1), 2021 
Sinambela, E., Manik, S., \& Pangaribuan, R. E. (2015). Improving students' reading comprehension achievement by using K-W-L strategy. English Linguistics Research, 4(3), p.13-29.

Soemantri \& Susany. 2011. Reading Comprehension Problems Encounted by The Students of Higher Education. Jurnal Computech\&Bisnis, Vol. 5, No. 2, Desember 2011, 74-80

Stahl. 2011 . Applying New Visions of Reading Development in Today's Classrooms. New York: Guilford. (p.53-55)

Suleman, I.H., \& Naseer, U.D. 2017. Effects of Computer-Assisted Instruction (CAI) on Students' Academic Achievement in Physics at Secondary Level. Computer Engineering and Intelligent Systems. 8(7). p.9-17

Intensive Journal, Vol. 4(1), 2021 